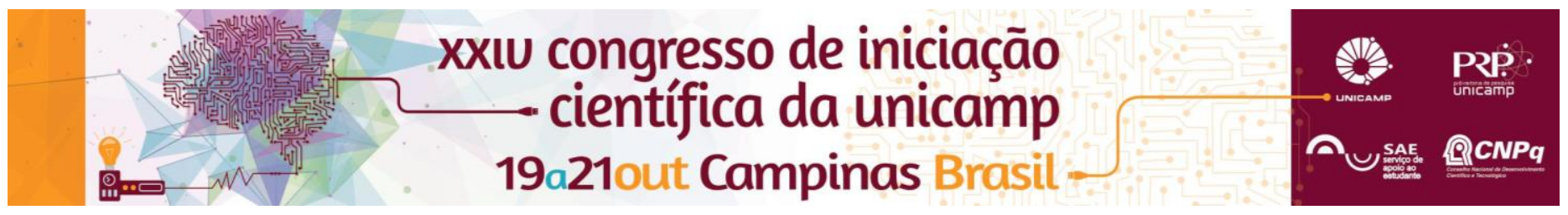

\title{
Cadeia Produtiva do Veículo Elétrico: Mapeamento das principais empresas de componentes presentes no Brasil
}

\section{Henrique Botin Moraes*, Flávia L. Consoni}

\section{Resumo}

Os veículos elétricos (VE) apresentam-se como uma tecnologia capaz de auxiliar no combate à emissão de gases poluidores da atmosfera. Sua Cadeia Produtiva começou a se desenvolver globalmente, trazendo ao Brasil questionamentos sobre sua difusão. Dessa forma, questiona-se: existe possibilidade do Brasil figurar como produtor de veículos neste processo? Os resultados mostram que, se há cadeia, ela ainda está em estágio embrionário e, no curto prazo, são poucas as perspectivas de que o Brasil venha a figurar como produtor e desenvolvedor de VE.

Palavras-chave: Veículo Elétrico, Cadeia Produtiva, Insdústria Automobilística Brasileira

\section{Introdução}

O Veículo Elétrico (VE) posiciona-se como uma das tecnologias verdes capazes de atuar na diminuição da emissão dos gases poluentes da atmosfera, que afetam, em especial, a saúde humana nos grandes centros urbanos. O Brasil é um importante player da indústria automobilística global e deve analisar a produção destes veículos nacionalmente. Para tanto, é importante identificar e analisar a Cadeia Produtiva, ou seja, o conjunto de atores responsáveis pelo desenvolvimento, produção e comercialização do produto, que são essenciais para o desenvolvimento deste mercado (Gereffi, 1999).

Desta forma, buscou-se neste PIBIC analisar quais as possibilidades do Brasil se tornar um produtor de VE a partir da identificação e categorização dos seus principais atores e sua distribuição em território nacional.

\section{Resultados e Discussão}

Para mapear os atores presentes no Brasil, foram feitas entrevistas presenciais com a Associação Brasileira do Veículo Elétrico (ABVE), além de extensa consultas a dados secundários.

Conforme Figura 1, existe uma grande concentração destes atores nas regiões Sul e Sudeste do Brasil, com destaque para o Estado de São Paulo, por ser o maior polo industrial e comercial, e concentrar a maior parte das atividades de pesquisa e desenvolvimento do país.

Destaca-se também a grande presença de Startups na composição desta cadeia que representam a possibilidade de renovação do modelo de negócios utilizado. Neste sentido, começa a surgir um segmento que passa a enxergar o veículo mais como um serviço, que atende às necessidades de locomoção do usuário, do que como um produto que pode apresentar pouca utilidade e alto custo quando parado em uma garagem.

Por fim, é notável a falta de atores que estejam ligados à temática da infraestrutura de recarga no país, os eletropostos. Este ponto foi essencial em algumas experiências internacionais de sucesso, como na Noruega (IEA, 2016), garantindo segurança e autonomia aos proprietários.
Figura 1. A Cadeia Produtiva do Veículo Elétrico no Território Brasileiro

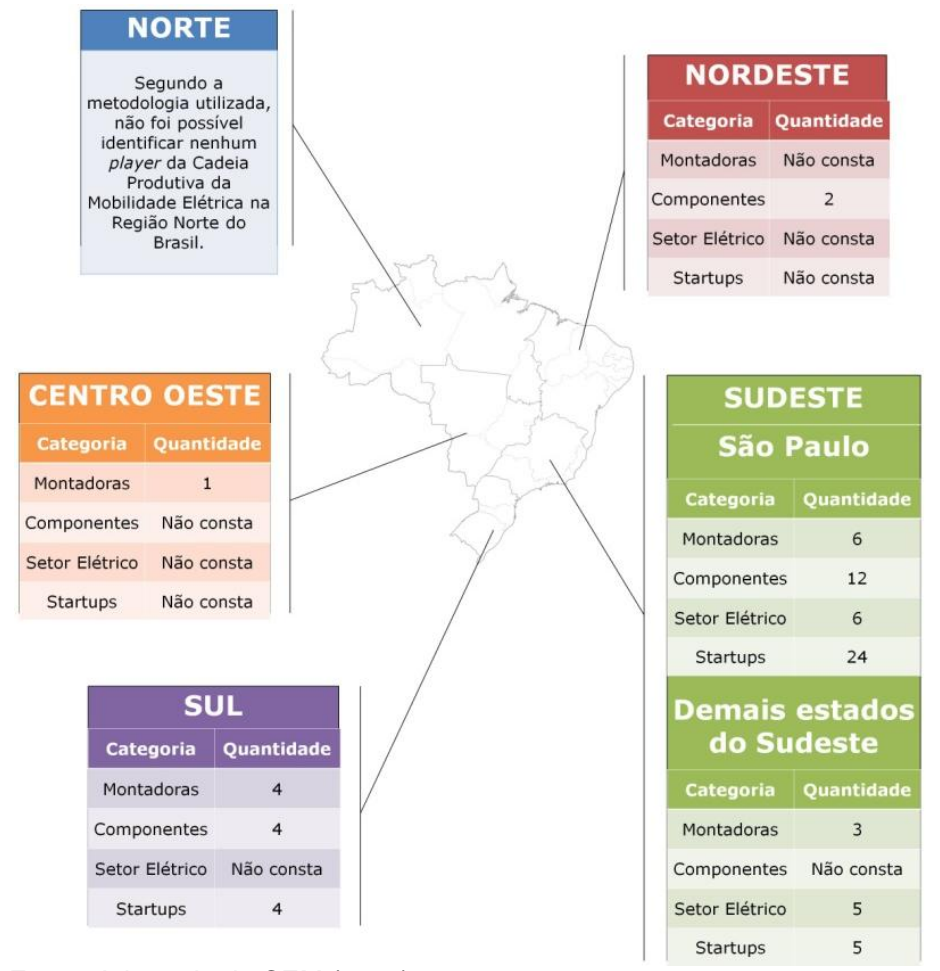

Fonte: Adaptado de CEM (2008).

\section{Conclusões}

Em território nacional ainda são escassos os esforços para a criação de uma Cadeia Produtiva brasileira que viabilize a produção em larga escala do VE no país. É necessário que, além de um marco institucional adequado e com políticas apropriadas para a promoção deste mercado, também haja uma integração de toda a Cadeia, juntamente com outros atores deste cenário, como o Estado e os Institutos de Ciência e Tecnologia, para que o VE possa se estabelecer.

CEM. Centro de Estudos da Memória. Brasil Regiões 2. 2008 Disponível em: <http://www.fflch.usp.br/centrodametropole/154> Acesso em: 27/jun./2016

GEREFFI, G. A commodity chains framework for analyzing global industries. Institute of Development Studies, Duke University, 1999.

IEA. International Energy Agencie. Global EV Outlook 2016. Disponível em:<http://www.iea.org/publications/freepublications/publication/Global_E V_Outlook 2016.pdf> Acesso em: 09/jun./2016. 